\title{
Clinico-Hematological Profile in Patients with Chronic Myeloid Leukemia
}

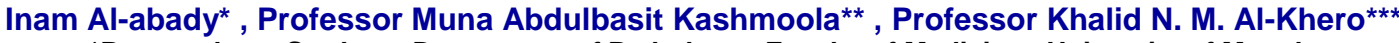 \\ ${ }^{*}$ Postgraduate Student, Department of Pathology , Faculty of Medicine , University of Mosul , \\ ${ }^{* *}$ Department of Pathology, Faculity of Medicine , University of Mosul , ${ }^{* * *}$ Department of \\ Medicine, Faculity of Medicine, University of Mosul , Mosul , Iraq \\ Correspondence: anaamghanm1988@gmail.com
}

(Ann Coll Med Mosul 2021; 43 (1):1-9).

Received: $14^{\text {th }}$ Octo. 2020; Accepted: $14^{\text {th }}$ Dece. 2020.

\begin{abstract}
Background: Chronic myeloid leukemia $(\mathrm{CML})$ is a clonal malignant neoplasms of pluripotent hematopoietic stem cell described by the excessive proliferation of mature granulocytes and their precursors in the bone marrow and peripheral blood. It is characterized by the presence of Philadelphia chromosome, a translocation between chromosome 9 and 22 or BCR-ABL1 gene.

Objectives: To evaluate clinical and hematological parameters in patients with chronic myeloid leukemia and to assess the risk stratification of these patients according to Sokal and European Treatment Outcome Study (EUTOS) scoring systems.

Setting: This case series study conducted at Ibn-Sina Teaching Hospital/Outpatients Hematology Department from November 2019 to April 2020.

Patients and methods: Total seventy patients with chronic myeloid leukemia included in this study. They involved 64 old cases and 6 new cases. The records of old cases were reviewed for clinical history, clinical examination, previous blood counts, bone marrow study and genetic study, where ever it was available. For new cases clinical history and physical examinations were noted. Complete blood pictures, biochemical tests and molecular study (BCR-ABL) were done at private laboratory. The BCR-ABL done by real-time reverse transcription polymerase chain reaction using Xpert BCR-ABL Ultra test on Cepheid GeneXpert@ Dx System. All patients were categorized into different risk groups by using Sokal and European Treatment Outcome Study scores that calculated according to standard formulae.

Results: The males were $(57.1 \%)$ of patients and females were $(42.9 \%)$ with male to female ratio was $1.33: 1$, their age ranged from 16-82 years with a mean of 41.9 years. The most common complains were fatigue $(87.1 \%)$, fullness in the abdomen (78.6\%) and constitutional symptoms (64.3-74.3\%). About $96 \%$ of patients had splenomegaly at presentation. The mean total leucocyte count was $153.7 \times 10^{9} / \mathrm{L}$, basophilia found in $(72.9 \%)$ of patients and anemia in (85.7\%) of them. By Sokal score, $(25.7 \%)$ of patients were categorized as low risk, (52.8\%) as intermediate risk and $(21.4 \%)$ as high risk. According to EUTOS score, $(60 \%)$ of patients were categorized as low risk, while $(40 \%)$ of them as high risk. There were significant differences in high and low risk groups between two scoring systems (P-values $0.016,0.000)$.

Conclusion: Middle age groups (35-54 years) were commonly affected by chronic myeloid leukemia and males were predominance over females. Fatigue, fullness in the abdomen were the most common complains, while splenomegaly was the most common clinical sign. Majority of the patients, when categorized by the Sokal score, fall under the low- and intermediate-risk groups, the same is true for the EUTOS score, which, however, does not have an intermediate risk category.
\end{abstract}

Keywords: chronic myeloid leukemia ; clinical parameters; hematological parameters; EUTOS; Sokal .

$$
\begin{aligned}
& \text { الملف السريرى المختبرى للى المرضى المصابين بسرطان الام } \\
& \text { النقوى المزمن المزي }
\end{aligned}
$$

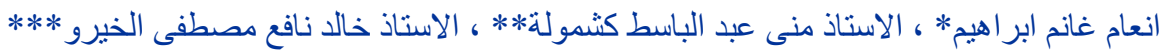

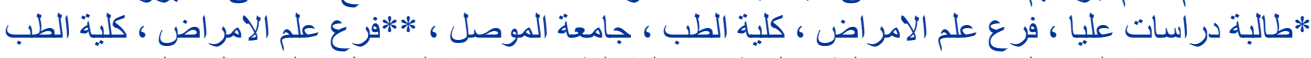

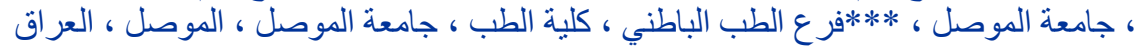




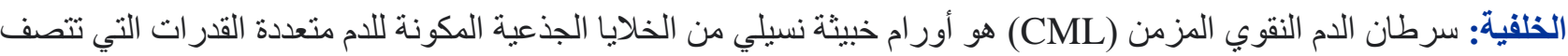

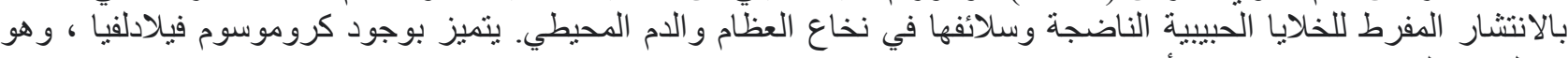

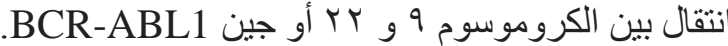
الأهداف: التقييم المعايير السريرية و الدموية في المرضى الذين يعانون من سرطان الدم النخاعي المزمن (CML) ولتقبيم طبقات

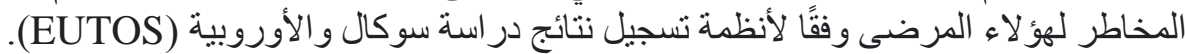

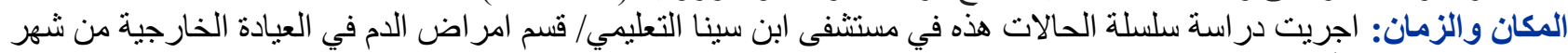

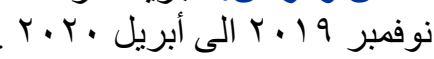

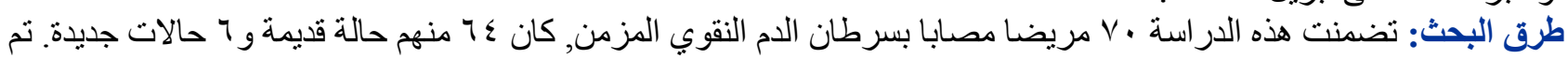

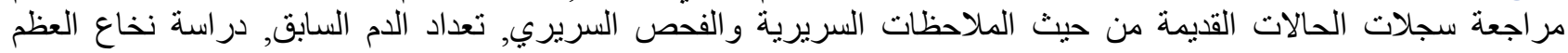

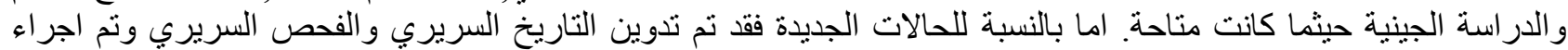

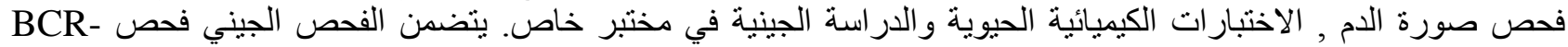

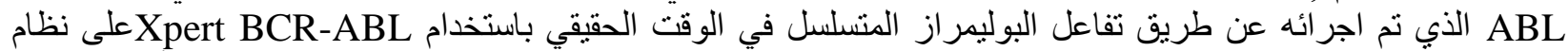

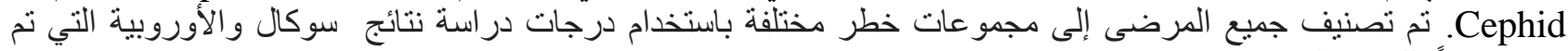
حسابها وفقًا للصيغ القياسية.

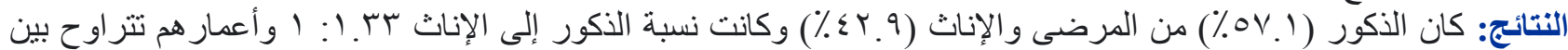

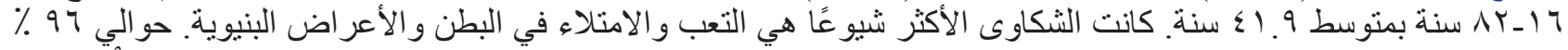

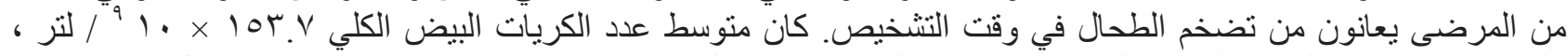

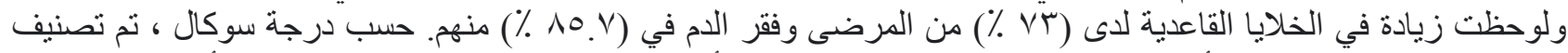

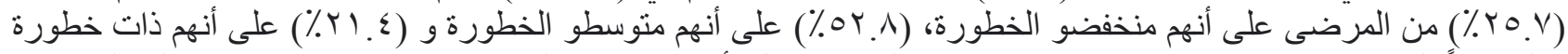

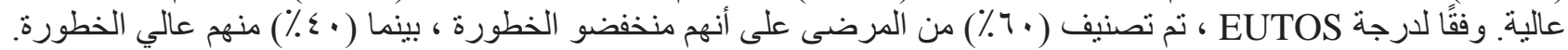
ك-نانت هناك فروق ذات دلالة إحصائية في مجموعات المخاطر العالية والمنخفضة بين نظامي تسجيل ( P-values 0.016,

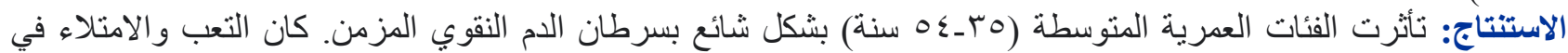

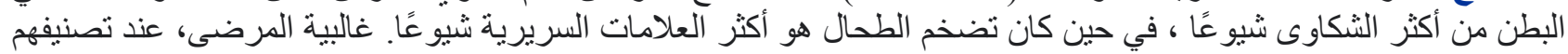

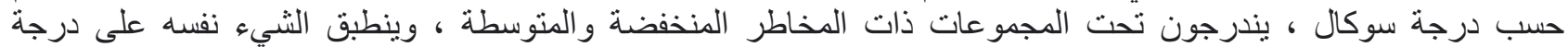

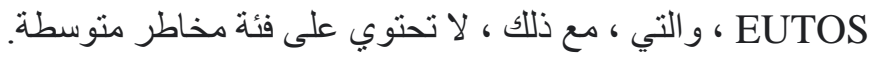

الكلمات المفتاحية: سرطان الدم النقوي المزمن, المعايير السريرية, المعايير الدموية, نظام Sokal EUTOS . .

\section{INTRODUCTION}

hronic myeloid leukemia is the most common type of the myeloprofilerative neoplasms (MPNs) described by overproduction of mature and immature blood cells in the peripheral blood, spleen and bone marrow ${ }^{1}$. It associated with reciprocal translocation between chromosome 9 and 22 which is cytogenetically noticeable as Philadelphia chromosome $(\mathrm{Ph})^{2}$, consequences in a fusion $B C R-A B L^{3}$. The outcome of this fusion $B C R-A B L$ gene is a constitutively active tyrosine kinase protein, $p 210 B C R-A B L$, resulting in the stimulation of numerous downstream signals that transmute hematopoietic stem cells, encourages cellular growing and overwhelms apoptosis, changes adhesion of the cell to bone marrow stroma and induces genetic instability ${ }^{2,4-6}$. Positive $B C R-A B L$ cells are unbalanced predisposed to develop numerous heterogeneous genomic aberrations, leading to the evolution from chronic phase to accelerated and blast phases as a result of alteration in the leukemic phenotype from chronic to acute ${ }^{7}$. Chronic myeloid leukemia records around $15 \%$ of totally leukemia cases in adult $^{8}$. The average age at the time of diagnosis varies between sixty and sixty five years ${ }^{9}, 10 \%$ of $\mathrm{CML}$ patients are children and adolescents ${ }^{10}$, It is slightly higher in males than females ${ }^{11}$.

Various prognostic systems have been used to stratify the risk of patients with CML, from which Sokal score and newly established scoring system named the EUTOS score ${ }^{12,13}$. These systems can guide treatment decisions, also useful for predicting survival in patients receiving tyrosine kinase inhibitors (TKIs) and cytogenetic response to treatment ${ }^{12,17}$. The Sokal score is based on age, spleen size, and peripheral blood platelet count and blast count. Patients are classified as being high-risk (Sokal score $>1.2$ ), intermediaterisk (0.8 to 1.2$)$, or low-risk $(<0.8)^{14-16}$. While 
EUTOS score is based on the percentage of basophils in the peripheral blood and the spleen size at diagnosis, the patients are classified as a high risk (EUTOS score of $\geq 87 \%$ ) or low risk $(<87 \%)^{17}$.

\section{AIMS OF STUDY}

1.To evaluate the hematological parameters of cases with $\mathrm{CML}$ and their clinical manifestation.

2. To assess the risk stratification of CML patients using Sokal and EUTOS scoring systems.

\section{PATIENTS AND METHODS}

This case series study was conducted on seventy patients with CML (6 new cases and 64 old cases) at Ibn-Sina Teaching Hospital/ Outpatient Hematology Department from November 2019 to April 2020. The records of old cases were reviewed for clinical notes, clinical examination, previous blood counts, bone marrow study and genetic study, where ever it was available. For new cases clinical history and physical examinations were noted, complete blood pictures, biochemical testes and genetic study were done at private laboratory.

Ten $\mathrm{mLs}$ of venous blood were aspirated from patients (new cases) by clean venipuncture and delivered into sterile EDTA tubes $(3 \mathrm{ml})$, then stored at $4 \circ \mathrm{C}$ to be used within three days for molecular study, second EDTA tubes $(2 \mathrm{ml})$ for doing complete blood pictures using ( NIHON KOHDEN and Hycount $3 \mathrm{~N}$ Hycel Coulter counter) and $(5 \mathrm{mls})$ in gel tubes for biochemical tests.

Stratification of risk groups calculated using the following formula. The Sokal score formula is as follows: Exp [0.0116 $\times$ (age in years - 43.4) + $0.0345 \times$ (spleen size $\mathrm{cm}$ below costal margin $\left.7.51)+0.188 \times(\text { platelet count } / 700)^{2}-0.563\right)+$ $0.0887 \times$ (blast cell \% in peripheral blood -2.10 )] (24), while EUTOS score formula is $(7 x$ basophils \% in peripheral blood $)+(4 \times$ spleen size cm below costal margin) ${ }^{17}$.

\section{Molecular Study for BCR-ABL1 Translocation}

Done by real-time reverse transcription polymerase chain reaction using Xpert BCR-ABL Ultra test on Cepheid GeneXpert@ Dx System. The procedure was done according to instruction of the kit.

The results are interpreted automatically by the GeneXpert system from measured fluorescent signals and embedded calculation algorithms that are shown in the View Results window ${ }^{18,19}$.

\section{RESULTS}

A total of 70 patients with documented CML were enrolled in this study. Their ages ranged between 16 and 82 years, mean age was 41.9 years. Forty $(57.1 \%)$ were males with mean age 38.6 ranged from 16-72 years and 30 (42.9\%) were females with mean age 46.3 ranged from 1882 years. Male :Female ratio was 1.33:1. Overall most common age group affected was between 35-54 years (Figure 1).

The most common complain among males was fatigue, followed by fullness in the abdomen and constitutional symptoms, while in females the more common complain was bone pain. Among the enrolled CML patients: 67 patients (95.7\%) had splenomegaly at the time of presentation while hepatomegaly found in 15 patients (21.4\%) only (Table 1).

The mean total leucocyte counts was $153.7 \times 10^{9} / \mathrm{L}$ ranged from $29-436 \times 10^{9} / \mathrm{L}$. Twenty four patients (34.3\%) had neutrophilia and $51(72.9 \%)$ had basophilia. The majority of immature WBCs in the peripheral blood were myelocytes and metamyelocytes (Table 2). Sixty patients $(85.7 \%)$ had anemia, 35 of them were males (50\%) and 25 were females (35.7\%), normochromic normocytic type was the most common. Thrombocytosis had been observed in $15(21.2 \%)$ of patients. The mean LDH level was $792 \mathrm{U} / \mathrm{L}$ with a range of $312-1812 \mathrm{U} / \mathrm{L}$, seven patients $(10 \%)$ had elevated serum LDH level. The mean uric acid was $4.8 \mathrm{mg} / \mathrm{dl}$ with a range of 2$12.6 \mathrm{mg} / \mathrm{dl}$, serum uric acid was increased in eleven $(15.7 \%$ ) of cases. (normal range of serum uric acid is $3.5-7.2 \mathrm{mg} / \mathrm{dl}$ in males and $2.6-6 \mathrm{mg} / \mathrm{dl}$ in females, while normal LDH levels range from 140-280 unit/liter U/L). 
The results of bone marrow examination of 46 CML patients were available, $44(95.7 \%)$ of them were in chronic phase while $2(4.3 \%)$ patients were in accelerated phase at the time of diagnosis. All patients had hypercellular bone marrow with myeloid hyperplasia, the higher level of Myeloid / Erythroid ratio was 30/1. The erythropoiesis was decreased in 17 patients $(36.9 \%)$, while megakaryopoiesis was increased in 8 of them (17.4\%).
By Sokal score, $18(25.7 \%)$ of patients were categorized as low risk , 37(52.8\%) as intermediate risk and $15(21.4 \%)$ as high risk. By EUTOS score, $42(60 \%)$ of patients were categorized as low risk, while $28(40 \%)$ of them as high risk. There were significant differences in high and low risk groups between two scoring systems ( $\mathrm{P}$-values 0.016, 0.000).

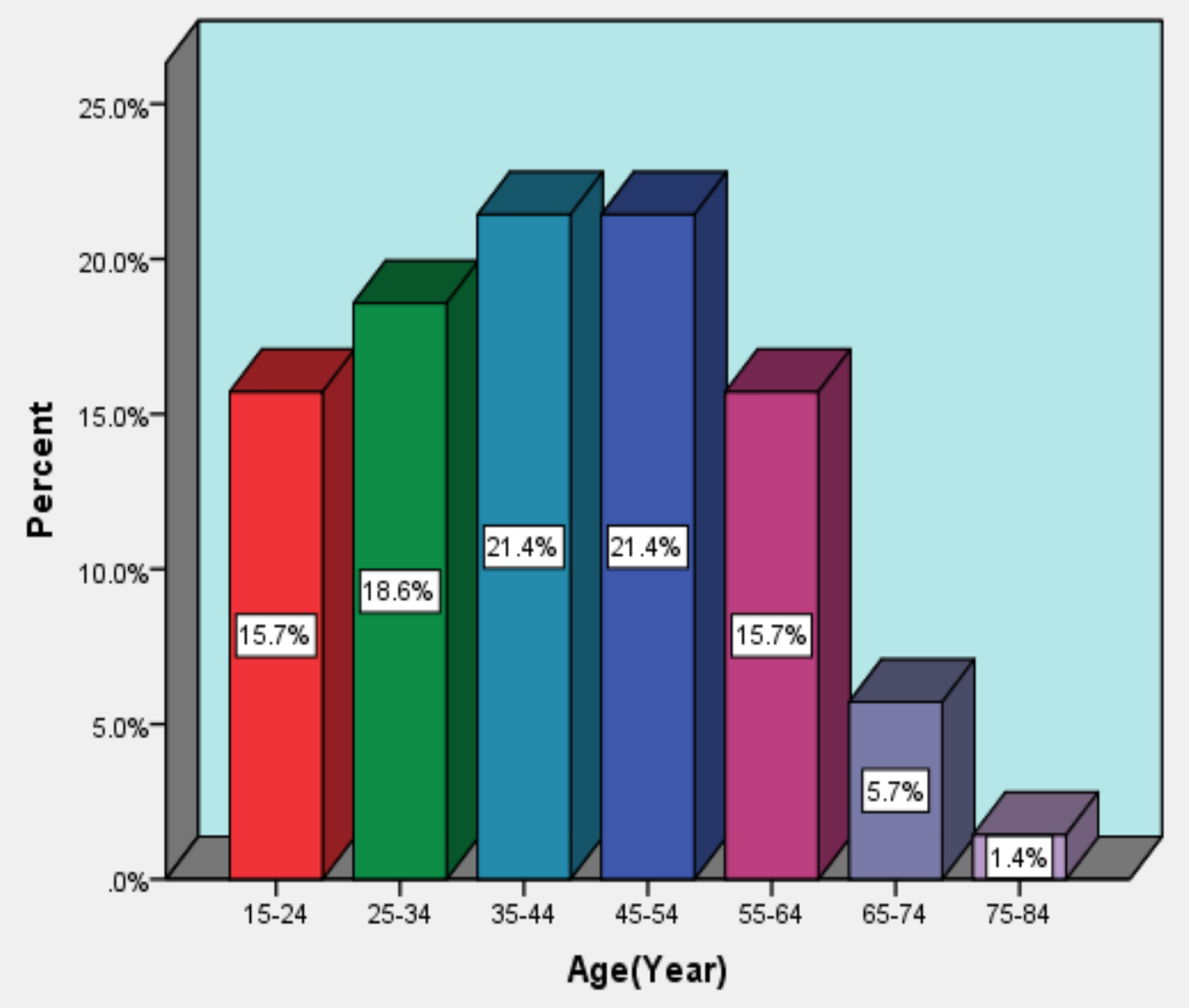

Figure 1: Age distribution of patients with $\mathrm{CML}$ 
Table (1) : Symptomatic presentation and clinical observation of patients with CML

\begin{tabular}{|c|c|c|c|c|}
\hline & & \multicolumn{2}{|l|}{ Sex } & \multirow{2}{*}{ Total $(n=70)$} \\
\hline & & Male(n=40) & Female $(n=30)$ & \\
\hline \multirow{2}{*}{ Fatigue } & Number & 32 & 29 & 61 \\
\hline & $\%$ of Total & $45.7 \%$ & $41.4 \%$ & $87.1 \%$ \\
\hline \multirow{2}{*}{ Palpitation } & Number & 14 & 16 & 30 \\
\hline & $\%$ of Total & $20.0 \%$ & $22.9 \%$ & $42.9 \%$ \\
\hline \multirow{2}{*}{ Dyspnea } & Number & 10 & 14 & 24 \\
\hline & $\%$ of Total & $14.3 \%$ & $20.0 \%$ & $34.3 \%$ \\
\hline \multirow{2}{*}{ Headache } & Number & 14 & 22 & 36 \\
\hline & $\%$ of Total & $20.0 \%$ & $31.4 \%$ & $51.4 \%$ \\
\hline \multirow{2}{*}{ Dizziness } & Number & 19 & 20 & 39 \\
\hline & $\%$ of Total & $27.1 \%$ & $28.6 \%$ & $55.7 \%$ \\
\hline \multirow{2}{*}{ Blurred vision } & Number & 15 & 13 & 28 \\
\hline & $\%$ of Total & $21.4 \%$ & $18.6 \%$ & $40.0 \%$ \\
\hline \multirow{2}{*}{$\begin{array}{l}\text { Burning pain in hands and } \\
\text { feet after hot bath }\end{array}$} & Number & 8 & 13 & 21 \\
\hline & $\%$ of Total & $11.4 \%$ & $18.6 \%$ & $30.0 \%$ \\
\hline \multirow{2}{*}{ Thrombosis } & Number & 0 & 2 & 2 \\
\hline & $\%$ of Total & $0.0 \%$ & $2.9 \%$ & $2.9 \%$ \\
\hline \multirow{2}{*}{ Bleeding } & Number & 11 & 11 & 22 \\
\hline & $\%$ of Total & $15.7 \%$ & $15.7 \%$ & $31.4 \%$ \\
\hline \multirow{2}{*}{ Pruritus } & Number & 8 & 9 & 17 \\
\hline & $\%$ of Total & $11.4 \%$ & $12.9 \%$ & $24.3 \%$ \\
\hline \multirow{2}{*}{ Bone pain } & Number & 21 & 27 & 48 \\
\hline & $\%$ of Total & $30.0 \%$ & $38.6 \%$ & $68.6 \%$ \\
\hline \multirow{2}{*}{ Fullness in the abdomen } & Number & 30 & 25 & 55 \\
\hline & $\%$ of Total & $42.9 \%$ & $35.7 \%$ & $78.6 \%$ \\
\hline \multirow{2}{*}{ Left hypochondrial pain } & Number & 8 & 4 & 12 \\
\hline & $\%$ of Total & $11.4 \%$ & $5.7 \%$ & $17.1 \%$ \\
\hline \multirow[b]{2}{*}{ Fever } & Number & 27 & 19 & 46 \\
\hline & $\%$ of Total & $38.6 \%$ & $27.1 \%$ & $65.7 \%$ \\
\hline \multirow{2}{*}{ Night sweats } & Number & 26 & 19 & 45 \\
\hline & $\%$ of Total & $37.1 \%$ & $27.1 \%$ & $64.3 \%$ \\
\hline \multirow{2}{*}{ Weight Loss } & Number & 29 & 23 & 52 \\
\hline & $\%$ of Total & $41.4 \%$ & $32.9 \%$ & $74.3 \%$ \\
\hline \multirow{2}{*}{ Anorexia } & Number & 29 & 20 & 49 \\
\hline & $\%$ of Total & $41.4 \%$ & $28.6 \%$ & $70.0 \%$ \\
\hline \multirow{2}{*}{ Pallor } & Number & 35 & 25 & 60 \\
\hline & $\%$ of Total & $50.0 \%$ & $35.7 \%$ & $85.7 \%$ \\
\hline \multirow{2}{*}{ Splenomegaly } & Number & 37 & 30 & 67 \\
\hline & $\%$ of Total & $52.9 \%$ & $42.9 \%$ & $95.7 \%$ \\
\hline \multirow{2}{*}{ Hepatomegaly } & Number & 9 & 6 & 15 \\
\hline & $\%$ of Total & $12.9 \%$ & $8.6 \%$ & $21.4 \%$ \\
\hline
\end{tabular}


Table (2) : Hematological parameters for patients with CML

\begin{tabular}{|c|c|c|c|c|c|c|c|c|c|}
\hline & \multicolumn{9}{|c|}{ Sex } \\
\hline & \multicolumn{3}{|c|}{ Male $(n=40)$} & \multicolumn{3}{|c|}{ Female $(n=30)$} & \multicolumn{3}{|c|}{ Total $(n=70)$} \\
\hline & Mean & Range & SD & Mean & Range & SD & Mean & Range & SD \\
\hline HB g/dl & 10.4 & $6.3-16.0$ & 2 & 9.8 & $7-14.3$ & 1.7 & 10.1 & $6.3-16$ & 1 \\
\hline HCT \% & 31.7 & $19-48$ & 6.3 & 30.3 & $20.4-45$ & 5.5 & 31.1 & $19-48$ & 6 \\
\hline RBC $10^{6} / \mathrm{MI}$ & 5.2 & $2.4-31.3$ & 6.8 & 3.6 & $2.7-5.8$ & .6 & 4.2 & $2.4-31.3$ & 4.4 \\
\hline MCV fl & 85.4 & $29.7-114.8$ & 18.2 & 86 & $64-119.3$ & 12.3 & 85.7 & 29.7-119.3 & 15.1 \\
\hline $\mathrm{MCH} \mathrm{Pg}$ & 30.7 & $26-38.3$ & 3.2 & 28 & $19.5-35.5$ & 3.7 & 29.2 & $19.5-38.3$ & 3.7 \\
\hline MCHC g/dl & 34.4 & $26.3-45.5$ & 4.2 & 33.5 & 25.2- 46.4 & 5.2 & 33.9 & 25. - 46.4 & 4.7 \\
\hline WBC $10^{9} / L$ & 162.1 & $36-436$ & 96.1 & 142.4 & $29-365$ & 79.4 & 153.7 & $29-436$ & 89.2 \\
\hline Neutrophils \% & 53.3 & $15-88$ & 18.4 & 55.5 & $11-80$ & 16.3 & 54.2 & $11-88$ & 17.4 \\
\hline Lymphocytes \% & 6.4 & $1-30$ & 6.5 & 6.9 & $1-24$ & 5.2 & 6.6 & $1-30$ & 5.9 \\
\hline Monocytes \% & 2.5 & $.0-14$ & 2.6 & 3.9 & $.0-15$ & 3.9 & 3.1 & $.0-15.0$ & 3.3 \\
\hline Basophiles \% & 4.4 & $.0-21$ & 3.9 & 6.9 & $.0-15$ & 4.9 & 5.5 & $.0-21.0$ & 4.5 \\
\hline Eosinophils \% & 3.6 & $.0-23$ & 4.4 & 3.7 & $.0-11$ & 2.9 & 3.7 & $.0-23.0$ & 3.8 \\
\hline Promyelocytes \% & 15.2 & $3-30$ & 7.8 & 8.5 & $1-22$ & 5.5 & 12.5 & $1-30$ & 7.6 \\
\hline Myelocytes \% & 24.3 & $.0-35$ & 9.4 & 20.9 & $2-44$ & 11.7 & 22.9 & $.0-44$ & 10.5 \\
\hline Band \% & 9.0 & $5-17$ & 6.9 & 28 & $28-28$ & $\cdot$ & 13.8 & $5-28$ & 11.1 \\
\hline $\begin{array}{c}\text { Metamyelocytes } \\
\%\end{array}$ & 14.8 & 28 & 8.7 & 14.3 & $10-20$ & 5.1 & 14.7 & 6- 28 & 6.9 \\
\hline Blast \% & 2.9 & $1-6$ & 2 & 2.3 & $1-6$ & 1.6 & 2.6 & $1-6$ & 1.8 \\
\hline PLT $10^{9} / \mathrm{L}$ & 359 & $98-1051$ & 198.5 & 401.3 & $154-1188$ & 247.7 & 377.1 & $98-1188$ & 220.2 \\
\hline MPV fl & 7.8 & $5.7-9.9$ & 1.1 & 8 & $5.1-10.3$ & 1.2 & 7.9 & $5.1-10.3$ & 1.1 \\
\hline PDW \% & 15.4 & $9.2-19.7$ & 3.4 & 15.6 & $10.3-18.7$ & 2 & 15.6 & $9.2-19.7$ & 2.6 \\
\hline
\end{tabular}

(HB: Hemoglobin; HCT: Hematocrit; RBC: Red blood cell; MCV: Mean corpuscular volume; MCH: Mean corpuscular hemoglobin; MCHC: Mean corpuscular hemoglobin concentration; WBC: White blood cell ; PLT: Platelets; MPV: Mean platelets volume; PDW: Platelet distribution width; SD: standard deviation)

\section{DISCUSION}

Seventy patients with CML included in this study with mean age was 41.9 years, a higher mean age $54,50.4$ years reported in Iraqi and Indian studies $\mathbf{2 0 , 2 1}$, while Iraqi studies in Mosul conducted by ALKhero, 2018 and AL-Khero, 2004 revealed mean age $41.2,46.2$ years ${ }^{22,23}$, that is consistent with our result. The young age of onset may be attributed to the effect of carcinogenic material and radiation that Iraqi people exposed to it from wars. In the other hand, studies in Iran, Western Libya, Pakistan and India reported mean age of 45.8 , 41.8, 39.5 and 38.6 years ${ }^{24-27}$.

Reports from India and Pakistan demonstrated males predominance among the enrolled $\mathrm{CML}$ patients with $M: F$ ratio were $(1.4: 1,1.6: 1)^{26,27}$. This finding may be due to greater exposure of males to environmental or occupational hazard. Anyway, females were predominate in Libyan study conducted by Jbireal et al., $2019^{25}$ with M:F ratio of $0.6: 1$.

Majority of CML patients in this study were in the $4^{\text {th }}$ and $5^{\text {th }}$ decade of life that corresponding to study obtained by Gupta and Kanetkar, $2020^{21}$, who found that $(45.94 \%)$ of their Indian patients were in the $5^{\text {th }}$ decade.

All CML patients in the present study were symptomatic at the time of presentation and the most common complaint was fatigue (87.1\%) followed by fullness in the abdomen (74.3\%), constitutional symptoms (weight loss $74.3 \%$, anorexia $70 \%$, fever $65.7 \%$ and night sweats $64.3 \%$ ). This was higher when compared with the Indian study which revealed common presentation were fatigue $(62.2 \%)$, fever $(40.5 \%)$ and fullness in the abdomen (35.1\%) ${ }^{21}$. Another Indian study revealed fullness in abdomen $66.6 \%$, fever $59 \%$, and fatigue $55.5 \%{ }^{27}$, this can be attributed to diverse sample size among studies, environmental factors and late presentation of our patients. 
Splenomegaly and anemia were the most common clinical signs in our patients, these findings consistent with that obtained by Kumar et al., 2019; Jameel and Jamil, $2006^{27,28}$. The Indian study revealed splenomegaly $54 \%$ and anemia $13.5 \%{ }^{28}$. In the research done by Srinivas et al., $2013^{29}$, $70 \%$ of patients had splenomegaly and $38 \%$ of them had anemia, the last two studies are disagree with the present study, this is may be due to late presentation of our patients who had high percentage of splenomegaly and anemia at the time of diagnosis.

Hepatomegaly account $21.4 \%$ of our patients, this observation was similar to studies conducted by Gupta and Kanetkar, 2020; Srinivas et al., 2013 21,29 , who reported hepatomegaly in $32.4 \%, 20 \%$ respectively, while Jameel and Jamil, 2006; Kumar et al., $2019^{27,28}$ had revealed hepatomegaly $57 \%$, $58 \%$, this may attributed to larger sample size of this study.

Bleeding was reported in $31.4 \%$ of the $\mathrm{CML}$ patients, this finding inconsistent with two studies in Pakistan that reported bleeding in $14.4 \%$ and $13.4 \%$ of cases ${ }^{26,30}$.

In a large multi-centered French study, at the time of diagnosis, the frequency of chronic phase and accelerated phase were $96.8 \%, 2.2 \%{ }^{31}$, this finding was similar to the current study. However, studies conducted by Ahmed et al., 2009 and Kumar et al.,2019 ${ }^{27,32}$, reported frequencies of chronic phase $77.8 \%$, $83 \%$, and accelerated phase $15.5 \%, 12 \%$. The possible explanation can be either, late presentation of the patients in our locality or the natural behavior of disease is different.

In this study, total mean WBCs count, HB and platelets count were $153.7 \times 10^{9} / \mathrm{L}, 12.3 \mathrm{~g} / \mathrm{dl}, 377.1$ $\mathrm{x} 10^{9} / \mathrm{L}$ respectively. Majority of patients $(72.9 \%)$ had basophilia with mean basophiles was $5.5 \%$. Myelocytes and metamyelocytes were the most common type of immature WBCs in the peripheral blood with mean $22.9 \%$, 14.7\%. In Chang et al. study in Pakistan, the mean WBCs, HB and platelets were $121 \times 10^{9}, 9.5 \mathrm{~g} / \mathrm{dl}$, $285 \times 10^{9} / \mathrm{L}$ respectively, that disagree with our results. In the same study, the myelocytes was the prominent immature WBCs in the peripheral blood with mean was $25 \%{ }^{26}$. Gupta and Kanetkar study,2020 in India ${ }^{21}$ showed mean WBCs, HB and platelets were $153.3 \times 10^{9} / \mathrm{L}, 9.7 \mathrm{~g} / \mathrm{dl}, 448$ $\times 10^{9} / \mathrm{L}$, absolute basophilia in the peripheral smear with mean was $3.27 \%$, accordingly mean WBCs and basophilia were shared to our finding. Kumar et al., $2019^{27}$ revealed mean WBCs, HB and platelets were $182 \times 10^{9} / \mathrm{L}, 9.4 \mathrm{~g} / \mathrm{dl}, 328 \times 10^{9} / \mathrm{L}$ respectively, thus mean platelets agree with that revealed in our study. The same study reported mean basophiles was $5.27 \%$.
The present study obtained elevated level of mean serum LDH, that attributed to disintegration of an increased number of leucocytes, while mean serum uric acid was found to be reasonable. These findings are similar to study conducted by Gupta and Kanetkar, $2020^{21}$

The six collected new cases in our study had no BM examination, however it is indicated for identification of the disease phase, the presence of myelofibrosis and to determining karyotype of patient ${ }^{33}$.

In the current study, a high percentage of patients assign under low and intermediate risk category by using Sokal score, this finding is in line with another studies in Iraq, Turkey, Egypt, India and Nigeria ${ }^{34-39}$, another studies reported a high percentage of patients were under high risk category by the same score ${ }^{40-42}$. This can be explained by ethnic variation, nature of disease and differences in sample size.

A high percentage of patients were under low risk category according to EUTOS score ${ }^{(39,40)}$, this is similar to the finding of this study. Other two studies conducted by UZ et al., 2013; Elbedewy and Elashtokhy, 2016, which revealed majority of patients were assign under low risk category $(88 \%$, 85\%) using EUTOS score ${ }^{35,36}$

The differences in percentage of $L R$ and $H R$ between the two scores can be explained that EUTOS score does not have an intermediate risk category and it depends on two variables only.

\section{CONCLUSION}

Most common age groups affected by CML were middle age (35-54 years). Males were more commonly affected than females. Fatigue, fullness in the abdomen and constitutional symptoms were the commonest complains, while splenomegaly and anemia were the most common clinical signs at presentation. Majority of patients had basophilia. By sokal score, most of patients fall under the lowand intermediate-risk categories, the similar is true for the EUTOS score, which, however, does not have an intermediate risk category. 


\section{REFERENCES}

1.Tabarestani S, Movafagh A. New Developments in Chronic Myeloidleukemia:Implications for Therapy. Int J cancer Manag 2016; 9(1):e3961. Doi: 10.17795/ijcp-3961.

2. Quintans Cardama A, Corts J. Molecular biology of bcr_abl1_positive chronic myeloid leukemia. Blood 2009; 113(8): 1619-30. Doi: 10.1182/blood-2008-03-144790.

3. Shtivelman E, Lifshitz B, Gale RP, Canaani E . Fused transcript of abl and bcr genes in chronic myelogenous leukaemia. Nature 1985; 315(6020):550-4. Doi: 10.1038/315550a0

4. An X, Tiwari AK, Sun Y,Ding PR, Ashby CR Jr, Chen ZS. BCR-ABL tyrosine kinase inhibitors in the treatment of Philadelphia chromosome positive chronic myeloid leukemia: a review. Leuk Res 2010; 34: 1255-68. Doi: 10.1016/j.leukers.2010.04.016.

5.Valent P. Emerging stem cell concepts for imatinib-resistant chronic myeloid leukaemia: implications for the biology, management, and therapy of the disease. $\mathrm{Br} \mathrm{J}$ Haematol 2008; 142(3):361-78. http://doi.org/10.1111lj.13652141.2008.07197.x

6. Drummond MW, Holyoake TL. Tyrosine kinase inhibitors in the treatment of chronic myeloid leukaemia: so far so good? Blood Rev 2001; 15:85-95. http://doi.orgl10.1054/blre.2001.0152

7. Hehlmann R, Hochhaus A, Baccarani M. European Leukemia Net. Chronic myeloid leukaemia. Lancet 2007; 370: 342-50. Doi: 10.1016/S0140-6736(07)61165-9.

8.Bortolheiro TC, Chiattone CS. Chronic myeloid leukemia: natural history and classification. Rev Bras Hematol Hemoter 2008; 30(1): 3-7.

9.Björkholm M, Ohm L, Eloranta S, Derolf A, Hultcrantz M, Sjo"berg J, et al. Success story of targeted therapy in chronic myeloid leukemia: a population-based study of patients diagnosed in Sweden from 1973 to 2008. J Clin Oncol 2011; 29: 2514-20. doi: 10.1200/JCO.2011.34.7146

10. Höglund M, Sandin F, Simonsson B. Epidemiology of chronic myeloid leukaemia: an update. Ann Hematol 2015; 94(2):S241-7. doi: 10.1007/s00277-015-2314-2.

11. Rohrbacher M, Hasford J. Epidemiology of chronic myeloid leukaemia (CML). Best Pract Res Clin Haematol 2009; 22: 295-302. Doi: 10.1016/j.beha.2009.07.007.

12. Sokal JE, Cox EB, Baccarani M, Tura S, Gomez GA, Robertson JE, et al. Prognostic discrimination in "good-risk" chronic granulocytic leukemia. Blood 1984 ; 63(4):789-99. PMID: 6584184

13. Baccarani M, Cortes J, Pane F, Niederwieser D, Saglio G, Apperley J, et al. Chronic myeloid leukemia: an update of concepts and management recommendations of European LeukemiaNet. J Clin Oncol 2009; 27(35):604151. doi:10.1200/JCO.2009.25.0779.

14. Bhamidipati PK, Kantarjian $H$, Cortes J, Cornelison AM, Jabbour E. Management of imatinib-resistant patients with chronic myeloid leukemia. Ther Adv Hematol 2013; 4(2):103-17. DOI: $10.1177 / 2040620712468289$.

15. Branford S, Rudzki Z, Walsh S, Parkinson I, Grigg A, Szer J, et al . Detection of BCR-ABL mutations in patients with $\mathrm{CML}$ treated with imatinib is virtually always accompanied by clinical resistance, and mutations in the ATP phosphate-binding loop(P-loop) are associated with a poor prognosis. Blood 2003; 102(1):27683. Doi: 10.1182/blood-2002-09-2896.

16. Savage DG, Antman KH. Imatinib mesylate: a new oral targeted therapy. New Engl J Med 2002;346(9):683-93.Doi:10.1056/NEJMra013339

17. Hasford J, Baccarani M, Hoffmann V, Guilhot J, Saussele S, Rosti G, et al. Predicting complete cytogenetic response and subsequent progression-free survival in 2060 patients with CML on imatinib treatment: the EUTOS score. Blood 2011; 118: 686-92 . Doi:10.1182/blood2010-12-319038.

18. Baccarani M, Deininger MW, Rosti G, Hochhaus A, Soverini S, Apperley JF, et al. European Leukemia Net recommendations for the management of chronic myeloid leukemia. Blood 2013; 122: 872-84. doi:10.1182/blood2013-05-501569

19. Hochhaus A, Saussele S, Rosti G, Mahon F-X, Janssen JJWM, Hjorth-Hansen, et al . Chronic myeloid leukaemia: ESMO Clinical Practice Guidelines for diagnosis, treatment and follow up. Annals of Oncolog 2017; 28(4):iv41-iv51. Doi:10.1093/annonc/mdx219.

20. Kashmoola MA. Leukemia in Mosul. A clincohaematological study. The Medical Journal Of Tikrit University 2002 ; 8:125-7.

21. Gupta S Kanetkar SR. Clinicohematological study spectrum of myeloproliferative neoplasms in a tertiary care hospital. Int. J. Res. Pharm. Sci. 2020; 11(3): 3710-18.DOI: https://doi.org/ 10.26452/ijrps.v11i3.2535

22. AL-Khero KNM. Effect of tyrosine kinase inhibitors in patients with chronic myeloid leukemia (cytogenetic, molecular response) in Mosul. Ann Coll Med Mosul 2018; 40(2): 1-8.

23. AL-Khero KNM. Haematological response of chronic myeloid leukemia to imatinib: (Preliminary study). Ann Coll Med Mosul 2004; 30(1):1-5.

24. Ayatollahi H, Keramati MR, Shirdel A, Kooshyar MM, Raiszadeh M,Shakeri S, Sadeghian $\mathrm{MH}$. BCR-ABL fusion genes and laboratory findings in patients with chronic 
myeloid leukemia in northeast Iran. Caspian $J$ Intern Med 2018; 9(1):65-70. DOI: 10.22088/cjim.9.1.65

25. Jbireal JM, Azab AE, Alzahani S, Elshareef $M$. Haematological and cytogenetic changes in CML patients treated with imatinib mesylate in Western Libya. Hematol Transfus Int J 2019; 7(3):50-7.

26. Chang F, Qazi RA, Khan M, Baloch S, Sahito MM. Clinico Hematological Profile and Phase Distribution of Chronic Myeloid Leukemia. Biol Med (Aligarh) 2015; 7: 257. doi: 10.4172/09748369.1000257

27. Kumar S, Gupta VK, Bharti A, Meena LP, Gupta V, Shukla J. A study to determine the clinical,hematological,cytogenetic, and molecular profile in CML patient in and around Eastern UP, India. J Family Med Prim Care 2019; 8(7):24505. Doi: $10.4103 / \mathrm{jmpc}$.jfmpc-307-19.

28. Jameel A, Jamil SN. Clinico-pathological profile of chronic myeloid leukemia. JPMI 2006; 20(3).

29. Srinivas KG, Patil $S$, Shashidhara. Epidemiological and clinical profile of patients with chronic myeloid leukemia at Health-Care Global, Bangalore Institute of Oncology. Indian J Med and Paediatr Oncol 2013; 34(3):211-12. Doi: 10.4103/0971-5851.123746.

30. Bhatti F, Ahmed S, Ali N. Clinical and hematological features of 335patients of chronic myelogenous leukemia diagnosed at single center in northern Pakistan. Clin Med Insights: Blood Disord 2012; 5:15-24.

31. Tardieu S, Brun-Strang C, Berthaud P, Michallet $M$, Guilhot $F$, Rousselot $P$, et al. Management of chronic myeloid leukemia in France: a multi-centered cross-sectional study on 538 patients. Pharmacoepidemiol Drug Saf 2005; 14:545-53. doi: 10.1002/pds.1046.

32. Ahmed R, Naqi N, Hussain I, Khattak BK, Nadeem M, lqbal J. Presentating Phases of Chronic Myeloid Leukaemia . JColl Physicians Surg Pak 2009 ;19 (8): 469-72. PMID: 19651006

33. Hidalgo-López JE, Kanagal-Shamanna R, Quesada AE, Gong Z, Wang W, Hu S, et al. Bone Marrow Core Biopsy in 508 Consecutive Patients with Chronic Myeloid Leukemia: Assessment of Potential Value. Cancer 2018; 124:3849-55.

34. AL-Khero KNM, AL-Mashhadani YAK, Gheni AA, Alobidy T, Aljumayli A. Evaluation of imatinib failure in patients with chronic myeloid leukemia. Journal of the Arab Board of Health Specializations 2017; 18(4):3-9.

35. Uz B, Buyukasik Y, Atay H, Kelkitli E, Turgut M, Bektas O, et al. EUTOS CML prognostic scoring systempredicts ELN-based 'event-free survival' better than Euro/Hasford and Sokal systems in $\mathrm{CML}$ patients receiving front-line imatinib mesylate. Hematology 2013; 18(5): 24751. DOI 10.1179/1607845412Y.0000000071

36. Elbedewy TA, Elashtokhy HE. The Utility and Applicability of Chronic Myeloid Leukemia Scoring Systems for Predicting the Prognosis of Egyptian Patients on Imatinib: Retrospective Study. J Leuk 2016; 4: 210. doi:10.4172/23296917.1000210

37. Heiba NM, Elshazly SA . SHP-1 expression in chronic myeloid leukemia: clinical significance and impact on response to imatinib treatment. Egypt J Haematol 2013; 38: 84-9.

38. Oyekunle AA, Osho PO, Aneke JC, Salawu L, Durosinmi MA. The predictive value of the Sokal and Hasford scoring systems in chronic myeloid leukaemia in the imatinib era. Journal of Hematological Malignancies June 2012; 2( 2) : 25-31. DOI:10.5430/jhm.v2n2p25

39. Ganguly S, Lakshmaiah KC, Jacob LA, Babu S, Dasappa L, Babu GKS. Performance of Sokal and Eutos Scores for Predicting Cytogenetic and Molecular Response in Newly Diagnosed Chronic Myeloid Leukemia-Chronic Phase Patients on Imatinib. Indian J Hematol Blood Transfus (Jan-Mar 2017); 33(1):82-6. DOI 10.1007/s12288-016-0667-x.

40. Aijaz J, Junaid N, Asif Naveed M, Maab R. Risk Stratification of Chronic Myeloid Leukemia According to Different Prognostic Scores. Cureus (March 20, 2020); 12(3): e7342. DOI 10.7759/cureus.7342

41. Usman M, Syed NN, Kakepoto GN, Adil SN, Khurshid M: Chronic phase chronic myeloid leukemia: response of imatinib mesylate and significance of Sokal score, age and disease duration in predicting the hematological and cytogenetic response. J Assoc Physicians India 2007; 55:103-7. PMID: 17571738

42. Syed NN, Usman M, Khaliq G, Adil SN, Khurshid M: Clinico-pathologic features of chronic myeloid leukemia and risk stratification according to Sokal score. J Coll Physicians Surg Pak 2006; 16:336-9. 